\title{
Рецепція проблеми творчого потенціалу майбутнього вчителя іноземних мов
}

\begin{abstract}
Анотація. B статті описано та охарактеризовано напрямки наукового дослідження психології творчого потенціалу особистості. Обтрунтовано актуальність вивчення проблеми розвитку творчого потенціалу майбутніх фахівців. Охарактеризовано пізнавальний, морально-етичний, комунікативний, естетичний та творчий потенціали людини, описано компоненти структури особистості, яким ці зазначені потенціали відповідають. Структуровано компоненти, виокремлені В. О. Моляко та Н.В. Кузьміною в структурі творчого потенціалу особистості, щчо стосуються вчителя іноземних мов. Обтрунтовано дочільність введення до структури творчого потенціалу вчителя іноземних мов сочіального компонента, описано його складові. Уточнено зміст понять «соиіальна креативність» та «комунікативна компетентність» в структурі творчого потенціалу вчителя іноземних мов.
\end{abstract}

Ключові слова: творчість, творчий потениіал, структура особистості, соиіальний компонент, соціальна креативність, комунікативна компетентність.

Вступ. Глибокі соціально-економічні зміни, які відбуваються в сучасному суспільстві, висувають абсолютно нові вимоги до розвитку особистості вчителя, а саме: вміння орієнтуватися в нових, часто невизначених ситуаціях, вміння самостійно приймати рішення та визначати найближчі та перспективні цілі, бути соціально активним, креативним та успішним. У зв'язку з цим особливого значення набувають задачі створення психолого-педагогічних умов розвитку творчої особистості педагога, його творчого потенціалу тощо.

Вихідні передумови. На сучасному етапі розвитку науки та освіти дослідження в галузі становлення творчої особистості $\epsilon$ найважливішим напрямком науково-теоретичних та практично зорієнтованих експериментів. На даний час достатньо глибоко розроблені питання щодо визначення психологічних аспектів та особливостей творчої діяльності (Дж. Гілфорд, О. І. Кульчицька, В. О. Моляко, К. Роджерс, Б. М. Теплов, Е. Торренс, В. Франкл, В.Д. Шадриков та ін.); вивчені проблеми творчих здібностей та можливості прояву креативності особистості (І.М. Біла, Д.Б. Богоявленська, Е. де Боно, В. М. Дружинін, О. В. Завгородня, Н.С. Лейтес, О.М. Матюшкін, Л.А. Найдьонова, Я.О. Пономарьов,
Дж. Рензуллі, А. Тейлор, Л. Л. Терстоун, Е.П. Торренс, Т.М. Третяк та ін.).

Розробкою проблеми творчого потенціалу у вітчизняній та зарубіжній науці займалися О.О. Глуховська, К.О. Гуськова, Е.В. Колеснікова, М.В. Колосова, Н.В. Кузьміна, Ю.М. Кулюткін, І.О. Мартинюк, О.М. Матюшкін, В.О. Моляко, В.Ф. Овчинніков, О.О. Попель, В.Г. Риндак та ін. В роботах цих вчених творчий потенціал розглядається як складне, інтегративне системне утворення, яке вміщує певні компоненти.

В працях Д. Б. Богоявленської, І. П. Волкова, В.М. Дружиніна, О.А. Кривопишиної, О.М. Матюшкіна, А. І. Савенкова, М.Б. Шумакової, О. Л. Яковлевої створено теоретичні передумови для вивчення особливостей діагностики творчого потенціалу особистості, його розвитку в шкільному та юнацькому віці.

При цьому В. О. Моляко [7; 8] неодноразово зазначає, що, не дивлячись на те, що дослідження проблеми творчого потенціалу особистості має достатньо довгу історію і в зарубіжній, і у вітчизняній психології, до цього часу існує безліч «білих плям» в цій галузі психологічних досліджень, які наголошують на актуальності здійснення подальших теоретико-методологічних та емпіричних досліджень. Однією 3 таких 
проблем, зазначає В.О. Моляко [7; 8], є те, що в «полі зору» педагогів, як правило, опиняються лише обдаровані особистості, a ті, які ще не розкрили свій творчий потенціал, мають досить мало шансів виявити свої креативні можливості. Актуальною також залишається проблема розвитку творчого потенціалу саме вчителя іноземної мови (адже у такому формулюванні цією проблемою науковці ще не займалися). При цьому виникають достатньо закономірні запитання: за яких умов навчання у вищій школі відбуватиметься актуалізація творчого потенціалу майбутнього вчителя іноземної мови? Які психологічні чинники найбільшою мірою сприяють ефективній творчій самореалізації студентів у процесі навчання у вищій школі? Чи можна мати високий рівень розвитку творчого потенціалу, але при цьому не виявляти своєї творчої сутності, тобто не бути творчою людиною в повному сенсі цього слова? Які складові творчого потенціалу саме вчителя іноземної мови? Всі ці питання потребують проведення спеціальних теоретичних та експериментальних досліджень, тому актуальність проблеми розвитку творчого потенціалу майбутнього вчителя іноземної мови не викликає сумнівів.

Отже, зважаючи на актуальність проблеми, яка аналізується в цій публікації, завданнями статті є:

1. Описати та охарактеризувати напрямки наукового дослідження психології творчого потенціалу особистості.

2. Обгрунтувати актуальність вивчення проблеми розвитку творчого потенціалу майбутніх фахівців.

3. Охарактеризувати пізнавальний, морально-етичний, комунікативний, естетичний та творчий потенціали людини, описати компоненти структури особистості, яким ці зазначені потенціали відповідають.

4. Структурувати компоненти, виокремлені В.О. Моляко та Н.В. Кузьміною в структурі творчого потенціалу особистості, що стосуються вчителя іноземних мов. Обгрунтувати доцільність уведення до структури творчого потенціалу вчителя іноземних мов соціального компонента, описати його складові. Уточнити зміст понять «соціальна креативність» та «комунікативна компетентність» в структурі творчого потенціалу вчителя іноземних мов.

Виклад результатів досліджень. Термін «потенціал» (від лат. potentia - сила, міць) аналізується в словниках у двох основних значеннях: 1) величина, що характеризує силове поле (електричне, тяжіння і т.д.) в даній точці (у фізиці); 2) сукупність наявних засобів, можливостей в певній галузі [9, с. 231].

Слово «потенціал» означає джерела, можливості, засоби, запаси, котрі можуть бути використані людиною чи навіть суспільством 3 метою досягнення конкретної мети. Так, в етимологічному плані, вважає В. О. Моляко, «під потенціалом розуміють можливість здійснювати щось (фізичний потенціал - запас фізичних сил; електричний потенціал — загальний енергетичний потенціал та ін.)» [8, с. 14].

В ієрархії потенціалів людини М. В. Хватова $[10$, с. 28-30] виокремлює наступні: біологічний, психічний, особистісний. Біологічний потенціал визначається як спільний та фундаментальний рівень ієрархії потенціалів індивіда. Він має здатність перетворюватися як в діяльність фізичну, зовнішню по відношенню до нього самого, так і в діяльність психічну, внутрішню. При цьому психічна діяльність виконує функцію управління з огляду на фізичні дії, що докладає людина. Потенціал, який реалізується в межах психічної діяльності особистості, становить психічний потенціал індивіда. Ускладнення взаємовідносин між людиною та оточуючим світом, перш за все - суспільством, призводить до формування особистісного потенціалу (на основі психічного потенціалу). В науковій літературі зазначається, що від психічного особистісний потенціал відрізняється, перш за все, структурою, а також величиною.

Величина особистісного потенціалу, зазвичай, складає деяку частину від психічного. На відміну від генетично заданого біологічного потенціалу людини, iї психічний потенціал може, хоч і не кардинально, змінюватися з огляду на умови життя суб'єкта. 
В цих змінах неабияку роль відіграє особистість людини, чи, іншими словами, - особливості реалізації нею особистісного потенціалу. На відміну від двох попередніх видів людського потенціалу особистісний потенціал формується у кожного індивіда протягом всього його життя $[1 ; 7 ; 8]$.

В свою чергу особистість можна охарактеризувати 3 огляду на п'ять основних потенціалів, котрі відіграють роль динамічних домінант, що великою мірою спрямовують процес розвитку особистості, a саме: 1) пізнавальний потенціал; 2) морально-етичний потенціал; 3) комунікативний потенціал; 4) естетичний потенціал; 5) творчий потенціал [4, с. 57].

Ці потенціали, вважає Г. О. Ковальов [4, c. 59], відповідають наступним компонентам структури особистості: спрямованість людини чи ставлення людини до дійсності; можливості особистості, що вміщують ту систему здібностей, яка забезпечує успіх діяльності суб'єкта; характер чи стиль поведінки індивіда в соціальному середовищі; система управління, що впливає на процес саморегуляції «Я»; психічні процеси і стани особистості.

Ряд інших авторів, зокрема М.С. Каган [3, с. 120], на основі аналізу різних видів діяльності особистості виділяють п'ять потенціалів, характерних для людини: 1) гносеологічний, що визначається обсягом та якістю інформації - знаннями особистості про зовнішній світ, природу і суспільство; 2) аксіологічний, який характеризується системою ціннісних орієнтацій; 3 ) творчий, що окреслюється вміннями та навиками, здатностями людини до виконання тієї чи іншої дії; 4) комунікативний, який визначається комунікабельністю особистості; 5) художній, що детермінується художніми потребами особистості й тим, яким чином вони задовольняються.

Виокремлення в структурі особистості творчого потенціалу є, з одного боку, правомірним, тому що в останньому відображено роль творчої діяльності в житті людини в цілому, однак, з іншого боку, зв'язок творчого потенціалу лише з певним рівнем знань і вмінь особистості є недостатнім 3 огляду на більш високий рівень складності феномена творчої діяльності.

За концепцією О.М. Матюшкіна [6], більша частина психічно здорових людей має деякий творчий потенціал, який відрізняється за величиною у різних людей. Творчий потенціал складає основу психічного розвитку особистості, визначає темпи і напрямки становлення людини.

Як процес виявлення сутності особистості, вважає С.В. Хмельковська, творчий потенціал має фізіологічну, психологічну та соціальну сторони. Сукупність певних явищ, властивих кожній із названих сторін, створює уявлення про творчий потенціал особистості як системну якість, виявлення та функціонування якої здійснюється у деяких конкретних формах. Особливе місце у дослідженнях творчості посідає питання домінантів, за рахунок яких здійснюється реалізація творчого потенціалу особистості [11, с. 4].

У зв'язку з існуванням великої кількості думок вчених та науковців щодо змісту поняття «творчий потенціал», проаналізуємо існуючі теорії та концепції, які стосуються визначення, структури та характеристик поняття «творчий потенціал особистості», що дасть нам можливість охарактеризувати дефініцію «творчий потенціал майбутнього вчителя іноземних мов».

Так, В. В. Давидов [2] зазначає, що особистістю $є$ індивід, який має певний творчий потенціал. Тобто, творчий розвиток — це найвищий ступінь у формуванні особистості в цілому. Становлення творчого потенціалу особистості, вказує В. Флетчер $[12$, с. 10], залежить від рівнів творчої активності людини. У своїх дослідженнях В. Флетчер наводить наступні рівні формування творчої активності особистості:

1) творче засвоєння знань на основі та 3 урахуванням практики, предметної діяльності людини. Цей етап характеризується розумінням людиною знань, що засвоюються особистістю, а також особливостей практичної діяльності суб'єкта. Основною рисою даного етапу є те, що в процесі виховання спочатку соціальні сили постають детермінантами природних (сутнісних) сил 
людини, а потім своєю власною діяльністю суб'єкт перетворює їх на засоби та знаряддя власного життя, що дозволяє індивіду управляти собою. Сутність творчої активності полягає в тому, що кожне нове покоління якоюсь мірою раціоналізує використання ним успадкованих соціальних властивостей, сил і здібностей, а також нівелює чи виключає все те, що вже застаріло або застаріває, і людина виконує певні рекомбінації, що сприяє реалізації творчої особистості;

2) творча активність людини як шлях до знаходження дещо нового в набутому раніше досвіді, в уже відомих явищах соціального життя, а також в явищах природи. Цей етап $\epsilon$ критично-аналітичним чи самостійно-пошуковим. Знаходження (відображення, пізнання) нового в старому постає для людини початком самостійного творчого акту, взагалі нової творчості, тому що на даному етапі значно полегшується, a, за своєю суттю, - тільки починається вихід за межі пізнаного, поступ у сферу непізнаних до того часу явищ і процесів природи та суспільства. На даному етапі формування творчої активності особистості вихователь, вчитель і учень займають позицію тих, хто пізнає об'єкти, предмети, явища, процеси і т.д. Цей стан характеризується тим, що вчитель уже не може пояснити учневі того, з чим вони обидва зіткнулися. 3 цього часу розпочинається етап дійсно нової творчої активності. В даному випадку ані в науці чи мистецтві, ані в літературі чи техніці людина не може навчитися новій творчості: останнє досягається в процесі відображення, пізнання чогось раніше невідомого. Проблема з галузі «філософії творчості» переходить в сферу власне філософії, в галузь, яка має назву «генерування нових ідей» [12, с. 11-14].

Творчий потенціал В.О. Моляко розглядає як «ресурс творчих можливостей людини, здатність конкретної людини до здійснення творчих дій, творчої діяльності в цілому». Тобто, вважає вчений, «творча людина... потенційно здатна до творчості. Інша річ - у яких масштабах, у якому обсязі, на яких часових дистанціях, в яких сферах тощо - це вже потребує окремих уточнень у кожному конкретному випадку» $[8$, с. 14].

Динаміку творчого потенціалу суб'єкта В.О. Моляко бачить в організації, управлінні змістовою діяльністю свідомості за допомогою багаторівневої та розгалуженої диспозиційної системи, що проектується назовні через стратегії й пошуки мисленнєвої діяльності людини. До наукового обігу вчений вводить концептуальне поняття «стратегіальна організачія свідомості». Останнє визначається взаємозв'язком зовнішніх і внутрішніх умов за принципом детермінізму. Функція такої організації - «впорядкувати зміст потоку свідомості, знайти в хаосі конкретні системи, спроектувати їх та змоделювати, орієнтуючись також на об'єктивні показники, що задаються усіма тими вимогами, які існують в реальності (у випадках технічних систем — це вимоги щодо структур та функцій технологій виготовлення та моделювання: економічні, ергономічні, художні, екологічні)» [7, с. 86].

В дослідженнях Н.Ф. Вишнякової, О.О. Глуховської, К. О. Гуськової, В. М. Дружиніна, В. О. Кан-Калика, Н. В. Кузьміної, В. О. Моляко, Я. О. Пономарьова, С. О. Сисоєвої, Р. П. Скульського, С.В. Хмельковської та ін. в найбільш узагальненому вигляді творчий потенціал вчителя вміщує наступні складові: 1) потенційна складова; 2) мотиваційна складова; 3) когнітивна складова.

Спираючись на власні міркування щодо особливостей діяльності вчителя іноземних мов, ми доповнили ці компоненти наступними складовими, виокремленими В.О. Моляко [7; 8] в структурі творчого потенціалу особистості, а саме:

- мотиваційний компонент: допитливість, потяг до створення нового, до пошуку й розв'язання проблем;

- емоційний компонент: задатки, нахили; емоційне ставлення; інтуїтивізм;

- вольовий компонент: наполегливість, систематичність у роботі, цілеспрямованість, рішучість, працелюбність, сміливе прийняття рішень; творча спрямованість на пошуки аналогій, 
комбінування, реконструювання, зміна варіантів, економність у рішеннях, використанні часу, засобів тощо;

- інтелектуальний компонент: швидкість у засвоєнні нової інформації; нахили до постійних порівнянь, зіставлень, відбору; прояви загального інтелекту.

Також, спираючись на виокремлені Н.В. Кузьміною [5] складові творчого потенціалу вчителя, до інтелектуального компоненту ми відносимо інтелектуальну креативність.

До структури творчого потенціалу майбутнього вчителя іноземних мов ми ввели п'ятий компонент, який назвали «соціаль$\boldsymbol{\mu и м » . ~ В і н , ~ н а ~ н а ш у ~ д у м к у , ~ б у д е ~ в м і щ у в а т и ~}$ виокремлені В.О. Моляко [7; 8] складові:

- інтереси, їх спрямованість, частоту й систематичність проявів, домінування пізнавальних процесів;

- порівняно швидке та якісне оволодіння вміннями, навичками, прийомами, технікою праці, майстерністю виконання відповідних дій;

- здатність до реалізації власних стратегій і тактик у процесі розв'язання різних проблем, завдань, пошуку виходу зі складних, нестандартних, екстремальних ситуацій.

Також соціальний компонент включає складові, виділені Н. В. Кузьміною [5]:

- психологічна готовність до реконструювання діяльності у пошуках нових способів розв'язання творчих задач;

- способи врахування системи обмежень та вимог до розв'язання творчих задач, зумовлених професією та виробництвом;

- способи врахування системи вимог та обмежень до розв'язання задач 3 огляду на моральні принципи.

До соціального компоненту ми віднесли складову "соціальна креативність» (вона вміщує здатність до самоактуалізаціï, соціальну мотивацію, комунікативну компетентність, комунікативну (вербальну та невербальну) сенситивність, поведінкову сенситивність, соціальну уяву тощо).

Нами уточнено структуру комунікативної компетентності вчителя іноземної мови. Ми вважаємо, що комунікативна компетентність складається 3 лінгвістичної, соціолінгвістичної, стратегічної, соціальної та психологічної компетентностей. Так, під лінгвістичною компетентністю ми розумітимемо знання педагогом одиниць мови та здатність вміло оперувати ними; під соціолінгвістичною - здатність використовувати і перетворювати мовні форми відповідно до ситуацій спілкування зокрема та всього соціального контексту в цілому; під стратегічною - здатність використовувати комунікативні засоби для компенсації певних знань чи вмінь (в тому числі - й знань про партнерів та ситуації взаємодії, яких недостатньо фахівцеві для здійснення успішного спілкування); під соиіальною - здатність встановлювати та підтримувати стосунки 3 людьми, вміння поставити себе на місце іншого та досягти успіху в ситуаціях, які склалися в суспільстві. Психологічна компетентність визначається нами як здатність майбутнього вчителя іноземної мови до оволодіння власне психологічними ресурсами в спілкуванні, врахування психологічних особливостей партнерів по спілкуванню.

Також, спираючись на дослідження Н.В. Кузьміної [5], до структури творчого потенціалу майбутнього вчителя іноземних мов ми ввели «особистісний компонент», який вміщує виокремлені Н.В. Кузьміною [5] складові: 1) індивідуальні якості; 2) структури вмінь.

Висновки і подальші перспективи досліджень. Отже, саме творчий потенціал особистості є тим фундаментом, який становить основу для ідеальних умов життя людини: особистість вільно демонструє свої почуття, здійснює незалежні вчинки, тобто $є$ креативною в повному смислі цього слова. Більш детально структуру творчого потенціалу майбутнього вчителя іноземних мов буде описано в наступних наших публікаціях. Також спеціального емпіричного дослідження потребує перевірка всіх виокремлених складових у структурі творчого потенціалу педагога, i саме опису отриманих результатів будуть присвячені наші майбутні наукові доробки. 
Список використаних джерел:

1. Гуськова Е.А. Психологические условия реализации творческого потенциала студентов в учебно-воспитательном процессе вуза : дисс. ... канд. психол. наук : 19.00.07 / Екатерина Александровна Гуськова. - М., 2007. - 212 с.

2. Давыдов В. В. Теория развивающего обучения / Василий Васильевич Давыдов. - М. : ИНТОР, 1996. - $544 \mathrm{c}$.

3. Каган М. С. Человеческая деятельность: Опыт системного анализа / Моисей Самойлович Каган. - М. : Политиздат, 1974. - 328 с.

4. Ковалёв Г. А. Психология личности / Григорий Александрович Ковалёв. - М. : Просвещение, 1970. — $391 \mathrm{c.}$

5. Кузьмина Н.В. Творческий потенциал специалиста: Акмеологические проблемы развития / Н.В.Кузьмина // Гуманизация образования. - 1995. — № 1. - С. 41-53.

6. Матюшкин А. М. Концепция творческой одаренности / Алексей Михайлович Матюшкин // Вопросы психологии. — 1982. — №4. - С. 88-97.

7. Моляко В.А. Проблемы психологии творчества и разработка подхода к изучению одаренности / Валентин Алексеевич Моляко // Вопросы психологии. - 1994. - №5. C. 86-95.

8. Моляко В.О. Здібності, творчість, обдарованість: теорія, методика, результати досліджень : монографія / В.О. Моляко, О. Л. Музика // [за ред. В.О. Моляко, О. Л. Музики]. - Житомир : Рута, 2006. - 320 c.

9. Словарь иностранных слов / [под ред. П.Ф. Петрова]. - 15-е изд., испр. — М. : Рус. яз., 1988. $-608 \mathrm{c}$.

10. Хватова М. В. Потенциал личности и индивидуальное здоровье человека / М.В. Хватова // Материалы III Всероссийской Internet-конференции «Потенциал личности: комплексная проблема». - Тамбов, 2004. - С. 28-30.

11. Хмельковська С. В. Формування творчого потенціалу майбутніх вчителів іноземних мов у процесі фахової підготовки : дис. ... канд. пед. наук : 13.00 .04 / С. В. Хмельковська. - Херсон, 2005. - $221 \mathrm{c}$.

12. Fletcher W. The management of creativity / W. Fletcher // International Journal of Avertising. - 1990. - V. 9 (1). - P. 1-37.

Аннотация. B статье описаны направления научного исследования психологии творческого потенциала личности. Обоснована актуальность изучения проблемы развития творческого потенциала будущих специалистов. Дана характеристика познавательному, морально-этическому, коммуникативному, эстетическому и творческому потенциалам человека, описаны компоненты структуры личности, которым эти указанные потенциалы соответствуют. Структурировано компоненты, выделенные В.А.Моляко и Н.В.Кузьминою в структуре творческого потенциала личности, которые соответствуют учителю иностранных языков. Обоснована иелесообразность введения в структуру творческого потенциала учителя иностранных языков социального компонента, описань его составляющие. В статье уточнено содержание понятий «сочиальная креативность» и «коммуникативная компетентность» в структуре творческого потенциала учителя иностранных языков.

Ключевые слова: творчество, творческий потенциал, структура личности, социальный компонент, сочиальная креативность, коммуникативная компетентность.

Abstract. The article describes and characterizes the directions of scientific researches in Psychology of a creative potential of the person. The actuality of studying the problem of a creative potential of future specialists was justified. A cognitive potential, a moral one, the ethical potential, a communicative one, the aesthetic potential and a creative one of a person were characterized. The components in a structure of a person, which correspond to those indicated potentials, were described. The components distinguished by V.A. Molyako and N.V. Kuzmina in a a model of a creative potential of a person according to a teacher of foreign languages were structured. It was justified including into the structure of a creative potential of a teacher of foreign languages a social component. Its substructures were described. It was clarified the meaning of «social creativity» and «communicative competence» in the structure of a creative potential of a teacher of foreign languages.

Keywords: creativity, a creative potential, the structure of the person, a social component, social creativity, communicative competence. 